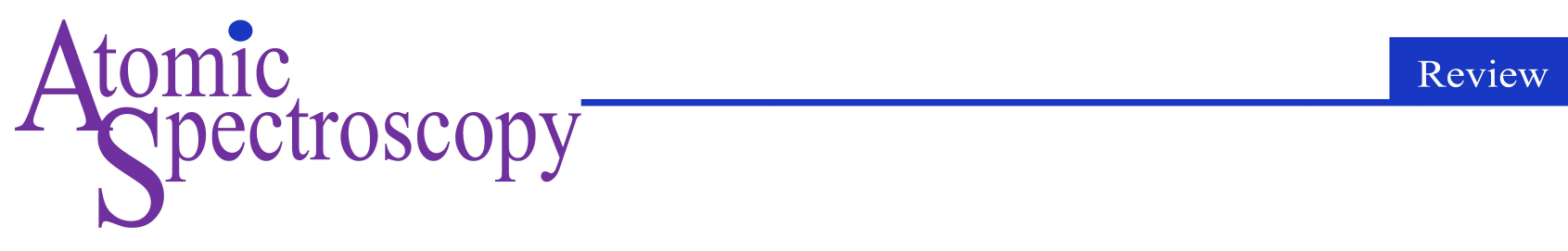

\title{
Matermetallomics: Concept and Analytical Methodology
}

\author{
Qing Li, ${ }^{a}$ Zhaoqing Cai, ${ }^{a}$ Yan Fang, ${ }^{a}$ and Zheng Wang a,b,* \\ ${ }^{a}$ Shanghai Institute of Ceramics, Chinese Academy of Sciences, Shanghai 201899, P.R. China \\ ${ }^{\mathrm{b}}$ Center of Materials Science and Optoelectronics Engineering, University of Chinese Academy of Sciences, Beijing 100049, P.R. China
}

Received: January 30, 2021; Revised: February 19, 2021; Accepted: February 19, 2021; Available online: March 6, 2021.

DOI: $10.46770 / A S .2021 .101$

ABSTRACT: The emerging field of matermetallomics refers to all research activities aimed at the clarification of the role and function of metallic elements in materials. This paper discusses the concept of matermetallomics and the related analytical techniques used for probing the interactions between structure-activity relationships. The main object of matermetallomics research is metallic elements in materials, and includes the significance and contributions to materials science. This paper also introduces the analytical approaches used in matermetallomics, which includes the techniques of imaging, spectroscopic, X-raybased, ion beam, MS-based and atomic spectrometry.

\section{INTRODUCTION}

Materials and their use are a part of all aspects of people's lives, they are very important for the development of human economic society and the continuous innovations developed through science and technology. They have been successfully synthesized and contain mechanical, physical, chemical properties or machinabilities, and more new materials continue to be synthesized to meet additional applications scenarios. As is known, the "Materials Genome Initiative" was proposed 10 years ago with the aim to shorten the research and development cycle of new materials from discovery to application in industry and to support rapid economic development. It combines big data and highthroughput screening to achieve efficient materials discovery and parameter optimizations, and greatly reduces the developmental costs for new materials. Thus, the quantitative relationships between composition, structure, process, properties, and performance are of great significance for research and development of new materials, which is also an important content of materials genomics. ${ }^{1}$

Recently, this technology has been successfully applied to some novel materials, such as energy materials, gas separation materials, alloy materials, catalytic materials, polymer materials and others for specific applications. ${ }^{2-7}$ Studies have shown that the composition as genes of materials is an important link in the chain of processing, structure, properties, and performance, which is worthy of attention and discussion.

Materials can be divided into metallic materials, inorganic nonmetallic materials, polymer materials and composite materials depending on their chemical composition (Fig. 1). Metallic materials mainly include two types: metallic simple substances and alloys. In the periodic table, about 50 kinds of metallic elements are labelled as metallic simple substances, and almost all metallic elements and some non-metallic elements have been prepared into alloys. These are important materials used in the fields of aerospace, energy, mechatronics and automobile because of their good thermal conductivity, strength, hardness, and ductility. Studies also show that these properties are directly related to the type and proportion of metals. Besides, inorganic nonmetallic materials, polymer materials and composite materials involve metallic elements, such as rare earth doped laser crystals, metal organic frameworks (MOF), Mxenes, and so on. MOFs are organic-inorganic hybrid materials with intramolecular pores formed by self-assembly of organic ligands and metal ions or clusters through coordination bonds. ${ }^{8}$ MXenes, a large family of transition metal carbides, nitrides, and carbonitrides, received considerable attention in recent years because they showed enhanced optical, thermal, mechanical, and electrical properties compared to their bulk counterparts. ${ }^{9}$ The different valence and coordination abilities of different metals results in a diversity of 

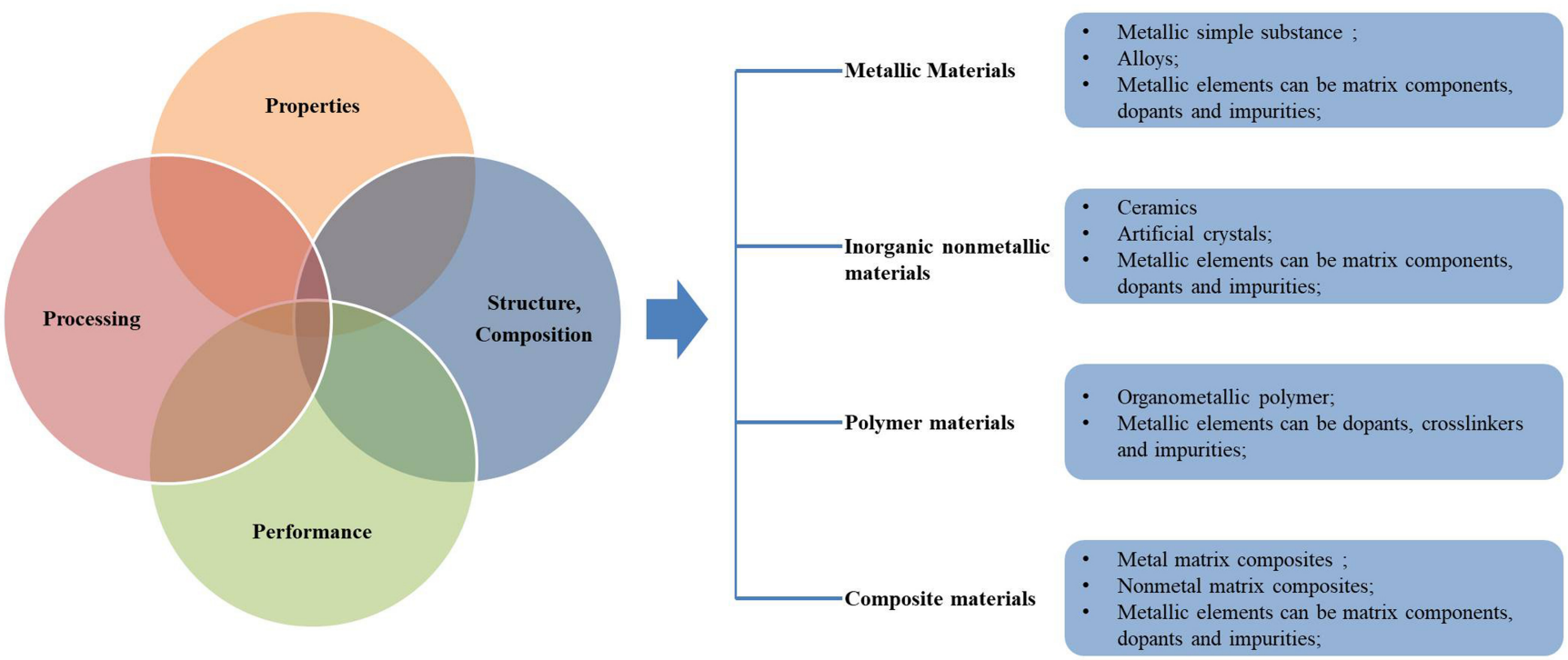

Fig. 1 Metallic elements play an important role in materials. Composition as genes of materials is an important link in the chain of processing, structure, properties, and performance. Metallic elements are used in all kinds of materials as matrix, dopants, impurities or crosslinkers.

\begin{tabular}{|c|c|c|c|c|c|c|c|c|c|c|c|c|c|c|c|c|c|c|}
\hline $\begin{array}{c}\text { hydrogen } \\
1 \\
\mathbf{H}\end{array}$ & & & & & & & & & & & & & & & & & & $\begin{array}{l}\text { nellum } \\
2 \\
\mathrm{He}\end{array}$ \\
\hline $\begin{array}{l}\frac{107079}{\text { intium }} \\
3\end{array}$ & $\begin{array}{l}\text { beryllum } \\
4\end{array}$ & & & & & & & & & & & & $\begin{array}{c}\text { boron } \\
5\end{array}$ & $\begin{array}{c}\text { carton } \\
6\end{array}$ & $\begin{array}{c}\text { nitrogen } \\
7\end{array}$ & $\begin{array}{c}0 x y s e n \\
8\end{array}$ & $\begin{array}{l}\text { fluotine } \\
9\end{array}$ & $\begin{array}{l}4.0265 \\
\text { nean } \\
10\end{array}$ \\
\hline Li & $\mathrm{Be}$ & & & & & & & & & & & & B & C & $\mathbf{N}$ & 0 & $\mathbf{F}$ & $\mathrm{Ne}$ \\
\hline $\begin{array}{c}6.941 \\
\text { sodidum } \\
\text { ont }\end{array}$ & $\begin{array}{l}9.01222 \\
\text { namasesum } \\
121\end{array}$ & & & & & & & & & & & & 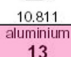 & 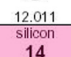 & 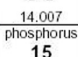 & $\begin{array}{l}\frac{15999}{\text { solutur }} \\
16\end{array}$ & $\begin{array}{l}18,998 \\
\text { chliberine } \\
17\end{array}$ & $\begin{array}{l}\text { argon } \\
18\end{array}$ \\
\hline $\mathrm{Na}$ & $\mathrm{Mg}$ & & & & & & & & & & & & Al & Si & $\mathbf{P}$ & $\mathrm{S}$ & $\mathrm{Cl}$ & Ar \\
\hline $\begin{array}{l}\text { Datssium } \\
19\end{array}$ & $\begin{array}{c}\text { calcioum } \\
20\end{array}$ & & $\begin{array}{c}\text { scandid } \\
21\end{array}$ & $\begin{array}{c}\text { titanium } \\
22\end{array}$ & $\begin{array}{c}\text { vanaditu } \\
23\end{array}$ & $\begin{array}{c}\text { chromit } \\
24\end{array}$ & & $\begin{array}{l}\text { irion } \\
26\end{array}$ & $\begin{array}{l}\text { conbat } \\
27\end{array}$ & 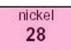 & $\begin{array}{c}\text { coppoer } \\
29\end{array}$ & $\begin{array}{l}\text { zince } \\
30\end{array}$ & $\begin{array}{l}\text { galioum } \\
\text { gallum }\end{array}$ & Detrmanum & $\begin{array}{c}\text { arsestic } \\
\text { arsentic } \\
33\end{array}$ & selentium & 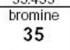 & $\begin{array}{c}\text { kyplon } \\
36\end{array}$ \\
\hline K & $\mathrm{Ca}$ & & $\mathrm{Sc}$ & Ti & V & CI & & $\mathrm{Fe}$ & Co & $\mathrm{Ni}$ & $\mathrm{Cu}$ & $\mathrm{Zn}$ & $\mathrm{Ga}$ & $\mathrm{Ge}$ & As & Se & $\mathrm{Br}$ & $\mathrm{Kr}$ \\
\hline $\begin{array}{l}\text { widdium } \\
37\end{array}$ & $\begin{array}{l}\text { strontium } \\
38\end{array}$ & & $\begin{array}{l}3 \text { trivi } \\
39\end{array}$ & $\begin{array}{l}\text { Zirconoutur } \\
40\end{array}$ & $\begin{array}{l}\text { niobium } \\
41\end{array}$ & 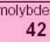 & & $\begin{array}{l}\text { Uthentumim } \\
44\end{array}$ & $\begin{array}{l}\text { troflium } \\
45\end{array}$ & $\begin{array}{c}\text { palladalum } \\
46\end{array}$ & $\begin{array}{l}\text { Silver } \\
47\end{array}$ & $\begin{array}{l}\text { cadratumim } \\
48\end{array}$ & $\begin{array}{l}\text { indium } \\
49\end{array}$ & $\begin{array}{l}\text { lin } \\
50\end{array}$ & antimony & $\begin{array}{l}\text { Tellutium } \\
52\end{array}$ & $\begin{array}{l}\text { ofine } \\
53\end{array}$ & $\begin{array}{c}\text { xenonn } \\
54\end{array}$ \\
\hline $\mathrm{Rb}$ & $\mathrm{Sr}$ & & Y & $\mathrm{Zr}$ & Nk & $\mathrm{M}$ & & Ru & Rh & Pd & $\mathrm{Ag}$ & $\mathrm{Cd}$ & In & Sn & $\mathrm{Sb}$ & $\mathrm{Te}$ & I & $X e$ \\
\hline $\begin{array}{c}\text { cansium } \\
55\end{array}$ & $\begin{array}{c}\text { Darium } \\
56\end{array}$ & & 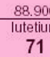 & 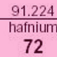 & 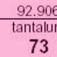 & $\begin{array}{l}\text { Uungst } \\
74\end{array}$ & & $\begin{array}{c}\text { ossmivim } \\
76\end{array}$ & 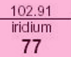 & $\begin{array}{l}\text { Platitumum } \\
78\end{array}$ & 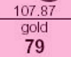 & $\begin{array}{l}\text { mercaciry } \\
80\end{array}$ & $\begin{array}{l}\text { thallumilum } \\
81\end{array}$ & $\begin{array}{l}\text { lead } \\
82\end{array}$ & $\begin{array}{l}\text { bismuth } \\
83\end{array}$ & $\begin{array}{l}\text { poloniumium } \\
{ }_{84}\end{array}$ & $\begin{array}{l}\text { astatitine } \\
85\end{array}$ & $\begin{array}{c}\text { Fadonon } \\
86\end{array}$ \\
\hline Cs & $\mathrm{Ba}$ & * & Lu & $\mathrm{Hf}$ & $\mathrm{Ta}$ & W & & Os & Ir & $\mathrm{Pt}$ & $\mathrm{Au}$ & $\mathrm{Hg}$ & TI & $\mathrm{Pb}$ & $\mathrm{Bi}$ & Po & At & $\mathbf{R n}$ \\
\hline $\begin{array}{l}\text { trancumim } \\
87\end{array}$ & $\begin{array}{l}\text { radium } \\
88\end{array}$ & $89-10$ & 103 & 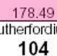 & $\begin{array}{c}\text { dubnouit } \\
10\end{array}$ & 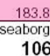 & & $\begin{array}{l}\text { hassium } \\
108\end{array}$ & $\begin{array}{l}\text { neititheriut } \\
109\end{array}$ & 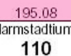 & $\begin{array}{l}\text { englganiun } \\
111\end{array}$ & $\begin{array}{c}\text { openticium } \\
112\end{array}$ & $\begin{array}{l}\text { nhlorium } \\
113\end{array}$ & $\begin{array}{l}\text { Aerovium } \\
114\end{array}$ & $\begin{array}{l}\text { noscovovium } \\
115\end{array}$ & 116 & $\begin{array}{l}\text { Emenssine } \\
117\end{array}$ & $\begin{array}{c}\text { Oagnaseson } \\
118\end{array}$ \\
\hline $\mathrm{Fr}$ & Ra & * & LI & Rf & Dk & $\mathrm{S}$ & & $\mathrm{Hs}$ & Mt & Ds & $\mathbf{R g}$ & $\mathrm{Cn}$ & Nh & FI & Mc & Lv & Ts & $\mathrm{Og}$ \\
\hline
\end{tabular}

\begin{tabular}{|c|c|c|c|c|c|c|c|c|c|c|c|c|c|c|}
\hline * Lanthani & $\begin{array}{l}57 \\
\text { La }\end{array}$ & $\mathrm{Ce}_{140.12}^{58}$ & $\begin{array}{l}59 \\
\mathbf{P r}\end{array}$ & $\begin{array}{l}60 \\
\mathbf{N d}\end{array}$ & $\begin{array}{l}\mathrm{P}^{61} \\
\mathrm{Pm}\end{array}$ & $\mathrm{Sm}_{150.36}^{62}$ & 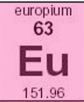 & $\mathbf{G}_{15725}^{64}$ & $\begin{array}{l}\text { refbum } \\
\text { Thb } \\
\text { Thb }\end{array}$ & $\begin{array}{l}66 \\
\text { Dy }\end{array}$ & $\begin{array}{l}\text { 67 } \\
\text { Ho } \\
164.93\end{array}$ & $\begin{array}{l}\mathrm{Er} \\
\mathrm{Er}\end{array}$ & $\begin{array}{l}\text { thumium } \\
\text { Trm }\end{array}$ & $\begin{array}{l}Y_{173.04}^{70} \\
\text { b }\end{array}$ \\
\hline & $\begin{array}{l}\text { actinum } \\
\mathrm{Ag}^{89} \mathrm{c}\end{array}$ & $\begin{array}{l}\text { loritum } \\
90 \\
\text { Th }\end{array}$ & $\begin{array}{l}\text { protactiniun } \\
91 \\
\mathrm{~Pa}\end{array}$ & $\begin{array}{l}\text { uraniun } \\
92 \\
\mathbf{U}\end{array}$ & $\begin{array}{l}\text { nepolunum } \\
93 \\
\mathrm{~Np}\end{array}$ & $\begin{array}{l}\text { Plutonium } \\
94 \\
\text { Pu }\end{array}$ & $\begin{array}{l}\text { amercium } \\
95 \\
\mathrm{Am}\end{array}$ & $\begin{array}{c}\text { cunium } \\
\text { 96 } \\
\mathrm{Cm}\end{array}$ & $\begin{array}{c}\text { berkeklum } \\
97 \\
\text { Bk }\end{array}$ & $\begin{array}{l}\text { cartifmivi } \\
\text { C8 } \\
\mathbf{C f}\end{array}$ & $\begin{array}{l}\text { einstitilium } \\
99 \\
\text { Es }\end{array}$ & $\begin{array}{l}\text { 每ermum } \\
\text { 100 } \\
\text { Fmm }\end{array}$ & $\begin{array}{l}\text { mendavevin } \\
101 \\
\text { Md }\end{array}$ & $\begin{array}{l}\text { nobelium } \\
102 \\
\text { No }\end{array}$ \\
\hline
\end{tabular}

Fig. 2 Elements have been used for doping. Almost all metallic and semi-metallic elements have been used for doping in the periodic table.

structures and functions. In summary, metallic elements are essential elements of materials composition. They can be used as matrix, dopant, crosslinkers and impurities in the preparation process, which covers almost all the metallic elements in the periodic table. In this paper, metallic elements as matrix are not discussed in detail, such as metallic simple substances, alloys, etc., since it is obvious that metals play an important role in such materials. 


\section{METALLIC ELEMENTS AS DOPANTS}

Doping is the purposeful incorporation of a small number of other elements or compounds into the material to change its composition, and making materials possess specific electrical, magnetic, and optical properties. At present, almost all the discovered metallic elements have been used in doped materials, such as crystals, ceramics, organic compounds, and other substances, which adds up to more than the non-metal elements. Table 1 lists the doping metallic elements in typical materials and related properties.

The doped elements cover almost all the metallic elements in the periodic table of elements and semi-metallic elements, such as B, Si, As, Se, Te etc., as shown in Fig. 2. The introduction of different metals into the same material can improve the performance of different aspects and broaden the application direction. Metallic element doping can effectively change the photoluminescence (PL) characteristics of the metal halide perovskite (the general structure is $\left.\mathrm{ABX}_{3}\right) \cdot{ }^{10}$ Intriguingly, $\mathrm{Mn}$ doping and lanthanide-doping both demonstrate multi-peak emission with PL peaks related to transitions from energy levels of the dopant ions. ${ }^{11,12}$ Spinel ferrite materials containing dopants have good electrical and magnetic properties and are used in various fields. It has been reported that $\mathrm{CoFe}_{2} \mathrm{O}_{4}$ nanoparticles have been doped with more than 20 kinds of metal elements to achieve applications in different fields. ${ }^{13}$ According to UV-Vis analysis, a blue shift was shown with $\mathrm{Ni}$ doping, ${ }^{14}$ while $\mathrm{Zn}$ doping produced particles with a similar shape, size $(5 \mathrm{~nm})$, and structure while possessing various magnetic anisotropies. ${ }^{15}$ The Aurivillius phase of $\mathrm{Bi}_{2} \mathrm{VO}_{5.5}$ is an interesting oxide ion conductor. ${ }^{16}$ The electrolyte ceramic membrane doped with $\mathrm{Cu}^{2+}$ and $\mathrm{Sb}^{5+}$ has the highest oxygen ion conductivity, reaching the $10^{-3}-10^{-1} \mathrm{~s} / \mathrm{cm}$ level in the working temperature range of $300-600{ }^{\circ} \mathrm{C}$. When doped with $\mathrm{Sb}^{5+}, \mathrm{Nb}^{5+}$, and $\mathrm{Ta}^{5+}$, it has a stable structure and a low thermal expansion coefficient and does not easily undergo phase transition. GaN-based magnetic semiconductor materials incorporated with metallic elements have been extensively studied for their potential applications in opto-electronics and spintronics. It was found that different metallic elements changed different degrees of magnetic performance. The non-magnetic dopant $\mathrm{Cu}$ has a $0.70 \mu \mathrm{B} / \mathrm{atom}$, and the magnetic moment of $\mathrm{Ag}$ doped $\mathrm{GaN}$ was larger than that of Pd doped because the $\mathrm{N}$ sites contribute $0.42 \mu \mathrm{B}$, which is much greater than any other $4 \mathrm{~d}$ metal doped GaN. In addition, there was a unique observation reported as a colossal magnetic moment in Re doped GaN. ${ }^{17}$ Atomically precise noble metal (mainly silver and gold) nanoclusters are an emerging category of promising functional materials. Without doping, the magnetic response of noble metal clusters is generally weak. Doping with ferromagnetic metals, such as $\mathrm{Fe}, \mathrm{Co}$, and $\mathrm{Ni}$, is a promising pathway to introduce magnetic properties into such clusters. ${ }^{18}$

In addition to the type of doped metal elements, closely related to the properties of the materials, the content of the doped elements also greatly affects the properties of the materials. Shobana et al. ${ }^{19}$ found that the increase in $\mathrm{Y}^{3+}$ content in yttrium doped cobalt ferrite prepared by sol-gel combustion can increase the crystallite size and decrease the conductivity of the nanoparticles. Yang ${ }^{20}$ synthesized the $\mathrm{Bi}_{2} \mathrm{~V}_{1-\mathrm{x}} \mathrm{MnxO}_{5.5-\delta} \delta$ electrolyte from $\mathrm{MnO}_{2}$.

Table 1 Doping and Properties of Some Representative Materials

\begin{tabular}{|c|c|c|}
\hline Material & Doping metal elements & Related performance \\
\hline Metal halide perovskites & $\begin{array}{l}\mathrm{Sb}, \mathrm{Bi}, \mathrm{Sn}, \mathrm{Pb} \text {, transition metals (e.g. } \mathrm{V}, \mathrm{Ni}, \mathrm{Cu}, \mathrm{Zn}) \text {, } \\
\text { lanthanide metals (e.g. } \mathrm{Sm}, \mathrm{Dy}, \mathrm{Er}, \mathrm{Yb}) \text {, and alkali metals } \\
\text { (e.g. } \mathrm{Li}, \mathrm{Na}, \mathrm{K}, \mathrm{Rb})\end{array}$ & $\begin{array}{l}\text { Optoelectronic properties (e.g., absorption band gap, } \\
\text { PLemission, and quantum yield (QY)) and stabilities } \\
\text { Power conversion efficiency (PCE), the } \\
\text { reproducibility and stability }\end{array}$ \\
\hline Ceramic-magnetic nanoparticles & $\begin{array}{l}\mathrm{Mg}, \mathrm{Al}, \mathrm{In}, 3 \mathrm{~d} \text { metals (e.g. Ti, } \mathrm{V}, \mathrm{Cr}, \mathrm{Mn}), 4 \mathrm{~d} \text { metals (e.g. } \\
\mathrm{Y}, \mathrm{Ag}, \mathrm{Cd} \text { ), rare-earth metals (e.g. La, Ce, Pr, Nd) }\end{array}$ & $\begin{array}{l}\text { Electrical } \\
\text { Structural } \\
\text { Optical characteristics }\end{array}$ \\
\hline Nitride ceramic phosphor & Rare-earth metals (e.g. Eu, Ce, Tb, Er, Gd) & Optical characteristics \\
\hline Zinc oxide semiconductor & $\begin{array}{l}\text { Transition metals }(\text { e.g. } \mathrm{Mn}, \mathrm{Cu}, \mathrm{Fe}) \\
\text { Noble metals }(\text { e.g. } \mathrm{Au}, \mathrm{Ag}, \mathrm{Pd}, \mathrm{Pt})\end{array}$ & $\begin{array}{l}\text { Photocatalytic properties (energy levels mobility, } \\
\text { conductivity, and optical and magnetic properties. } \\
\text { Gas sensing properties }\end{array}$ \\
\hline Graphite carbon nitride & $\begin{array}{l}\text { Alkali metals (e.g. Na, } \mathrm{K}) \text {, transition metals }(\text { e.g. Fe, } \mathrm{Cd} \text {, } \\
\mathrm{Co}, \mathrm{Mo}) \text {, rare-earth metals (e.g. } \mathrm{Ce}, \mathrm{Eu}, \mathrm{Se}, \mathrm{Y})\end{array}$ & $\begin{array}{l}\text { Photocatalytic properties (band gap, interlayer } \\
\text { resistance) }\end{array}$ \\
\hline Silicon Carbide Ceramics & Transition metals (e.g. Fe, Ti) & $\begin{array}{l}\text { Band diagram } \\
\text { Conduction } \\
\text { Spin-related-features }\end{array}$ \\
\hline Electrolyte ceramics & $\mathrm{Cu}, \mathrm{Sb}, \mathrm{Nb}, \mathrm{Ta}, \mathrm{Mn}$ & Oxygen ion conductivity \\
\hline Noble metal nanoclusters & $\mathrm{Fe}, \mathrm{Co}, \mathrm{Ni}$ & Ferromagnetic properties \\
\hline $\begin{array}{l}\text { GaN based magnetic } \\
\text { semiconductor materials }\end{array}$ & $\begin{array}{l}3 \mathrm{~d} \text { metals }(\text { e.g. } \mathrm{Fe}, \mathrm{Co}, \mathrm{Ni}, \mathrm{Cu}), 4 \mathrm{~d} \text { metals }(\text { e.g. } \mathrm{Ag}, \mathrm{Pd}) \text {, } \\
\text { rare-earth metals }(\text { e.g. } \mathrm{Eu}, \mathrm{Gd}, \mathrm{Ce})\end{array}$ & Ferromagnetic properties \\
\hline Structural ceramics & Rare-earth metals (e.g. La, Y, Ce) & $\begin{array}{l}\text { Compactness properties } \\
\text { Thermal conductivity } \\
\text { Mechanical properties } \\
\text { Electrical properties }\end{array}$ \\
\hline Conductive polymer & Transition metals (e.g. $\mathrm{Fe}, \mathrm{Co}, \mathrm{Ni})$ & Electrochemical activity \\
\hline
\end{tabular}


The electrolyte was the $\gamma$ phase in the range of $0.1 \leq x \leq 0.25$. The doped $\mathrm{Mn}^{4+}$ was reduced to $\mathrm{Mn}^{3+}$, and when the temperature was higher than $650{ }^{\circ} \mathrm{C}$, it was reduced to $\mathrm{Mn}^{2+}$, which was due to the release of $\mathrm{O}_{2}$. Alga ${ }^{21}$ believed that the solute was the $\gamma$ phase in the range of $0.075 \leq \mathrm{x} \leq 0.25, \mathrm{Mn}^{3+}$ in the range of $0.075 \leq \mathrm{x} \leq 0.10$, and $\mathrm{Mn}^{3+} / \mathrm{Mn}^{4+}$ in the range of $0.15 \leq \mathrm{x} \leq 0.25 . \mathrm{Mn}^{4+}$ increased with an increase in $\mathrm{MnO}_{2}$, and the highest oxygen ion conductivity was obtained when the doping amount of $\mathrm{MnO}_{2}$ was $\mathrm{x}=0.1$.

The dopants are mainly in the form of species (ion, atom, isotope) nanoparticles and compounds. For example, when adding metal halide salts (e.g. $\mathrm{SbCl}_{3}, \mathrm{BiCl}_{3}, \mathrm{VCl}_{3}, \mathrm{NiCl}_{2}, \mathrm{ZnCl}_{2}, \mathrm{SnCl}_{2}$, $\mathrm{SnCl}_{4}, \mathrm{PbCl}_{2}$ and $\mathrm{CuCl}_{2}$ ) as dopants to $\mathrm{CsPbCl}_{3}$ nanocrystals, the difference in the photoluminescence quantum yield (PLQY) enhancements was not due to the doping of these different doping metallic ions, but because of the varied ability of these metal compounds to release active chloride ions for surface passivation. $^{22,23}$ Recently, single-atom electrocatalysts (SACs), which comprise singly isolated metal atoms immobilized onto a heterogeneous support, have attracted attention as a robust analogue of organometallics. ${ }^{24}$ SACs are the ultimate form of size reduction of metal electrodes and maximize the efficiency of metal atom use. Different from $\mathrm{Pt}$ nanoparticle $\left(\mathrm{Pt}_{\text {nano }}\right)$ doping, single $\mathrm{Pt}$ atom doping can reduce Pt atom usage on the one hand, and selectively catalyze the hydrogen oxidation reaction (HOR)/hydrogen evolution reaction (HER) over oxygen reduction reaction (ORR) on the other hand. The temperature-frequency behavior of the dielectric permittivity $(9-300 \mathrm{~K} ; 100 \mathrm{~Hz}-1 \mathrm{MHz}$, and at $100 \mathrm{GHz}$ ) of $\mathrm{K}_{0.984} \mathrm{Li}_{0.016} \mathrm{TaO}_{3}$, containing the natural ratio of the $\mathrm{Li}$ isotopes $\left(7.56 \%\right.$ of ${ }^{6} \mathrm{Li}$ and $92.44 \%$ of ${ }^{7} \mathrm{Li}$, KLT-7) and only the ${ }^{6} \mathrm{Li}$ isotope (KLT-6), was studied. ${ }^{25}$ The results revealed that the activation energy for ${ }^{6} \mathrm{Li}^{+}$relaxation appeared to be smaller and the relaxation time pre-exponent was larger than for the ${ }^{7} \mathrm{Li}^{+}$ centers. The optical and photocatalytic properties of materials were usually related to the valence states of the elements, which should be paid attention to when doping. For ferric chloride doped polyvinyl alcohol (Fe: PVA) polymer films, the decrease of the refractive index in the visible range induced by UV exposure was related to the reduced oxidation state of the doping metal $\left(\mathrm{Fe}^{3+} \rightarrow \mathrm{Fe}^{2+}\right) \cdot{ }^{26}$ Structural ceramics are widely used in daily life, and have been extended to aerospace, integrated circuit, energy, and the environmental protection fields, such as alumina, silicon nitride, silicon carbide, and so on. In order to improve the compactness, thermal conduction and reduced sintering temperature, rare earth oxides are often doping, such as La/Y$\mathrm{Al}_{2} \mathrm{O}_{3}{ }^{27,28}$

Bimetallic/polymetallic doping has been tried because single metal doping sometimes cannot achieve satisfactory results. The $\mathrm{Ni}$ and $\mathrm{Mn}$ co-doping influence on electrical, structural, and optical characteristics of $\mathrm{CoFe}_{2} \mathrm{O}_{4}$ nanoparticles prepared via the co-precipitation route was reported. ${ }^{14}$ Bimetallic doping caused shifts of the absorption and emission band maxima in the luminescence spectra and the appearance of optical properties unattainable for mono-doped materials. ${ }^{29}$ Moreover, such systems often demonstrate the sensitization effect which allows a considerable enhancement of the luminescence intensity and thus avoids the limitations imposed by the concentration quenching effect. Experimental and theoretical studies have proven that incorporation of co-dopants advances the photocatalytic properties of graphite gallium nitride $\left(\mathrm{g}-\mathrm{C}_{3} \mathrm{~N}_{4}\right)$ photocatalyst more efficiently. ${ }^{30}$ Fan et al. ${ }^{31}$ first obtained $\mathrm{ZnO}$ nanorods by the hydrothermal method and then fabricated $\mathrm{Pt}$ and $\mathrm{Au}$ co-doped $\mathrm{ZnO}$ nanorods with the response of this bimetallic semiconductor hydrogen sensor much higher than those made of pure $\mathrm{ZnO}$ or single noble metal doped $\mathrm{ZnO}$.

In summary, doping improves the properties of materials by changing their composition or structure and is widely used in materials science. It was found that advanced materials with different properties of optical, magnetic, and electrical properties have been obtained by doping metallic elements. The doped elements include almost all metallic elements and semi-metallic elements, and the forms of doping involves ions, atoms, isotopes, valence states, nanoparticles, bimetallic/polymetallic doping. At the same time, the doping of non-metallic elements has been rarely reported.

\section{METALLIC ELEMENTS AS IMPURITIES}

In addition to doping by introducing metal elements into the material, the impurities of the raw materials and the contamination accompanying the process (such as the diffusion from crucible material and matrix material) will also affect the final quality and performance of the materials. Appropriate impurity species and contents are very helpful for the improvement of material properties. Cobalt and copper oxides have shown more important contribution to the observed electroactivity, and their presence as impurities in carbon nanotubes (CNTs) should be considered in the evaluation of their electrochemical response. ${ }^{32}$ It is considered that the ferromagnetism of some fullerene polymers and graphite, such as hard carbon phase samples, is not related to fullerene at all. ${ }^{33}$ Most of the works published previously as evidence of ferromagnetism in fullerene polymers synthesized at high pressure high temperature (HPHT) conditions can be explained by contamination with magnetic impurities. Formation of iron carbide $\left(\mathrm{Fe}_{3} \mathrm{C}\right)$ due to the reaction of metallic iron with fullerene molecules explains the observed Curie temperature of close to 500 $\mathrm{K}$ and the levels of magnetization reported for "magnetic carbon."

However, the existence of some impurities with the content exceeding a certain limit often causes adverse effects and the impurity removal process usually should be carried out. Metallic impurities such as iron, chromium and titanium can reduce the carrier diffusion length in polysilicon. In polysilicon cells, copper affected not only the composition of the substrate, but also the composition of the emitter and, more importantly, it affected the 
performance of the cell. ${ }^{34}$ Pumera et $a l .{ }^{35}$ investigated the electrochemical response of carbon nanotubes containing different amounts of impurities towards the reduction of an important biomarker, hydrogen peroxide, and the oxidation of an important impurity marker. They found that the borderline between being redox active/inactive for iron-based impurities was in the middleppm range.

\section{METALLIC ELEMENTS AS CROSSLINKERS}

Metal coordination is a special non-covalent interaction with both high bond energy and dynamic characteristics, for which metal ions are widely used as crosslinkers to assemble and regulate materials ${ }^{36}$ and to broaden the properties and applications prospects of materials. For example, crosslinking can fix the structure of polymer micelles and improve the stability of polymer micelles, and the use of some chemicals can be avoided in the formation of non-covalent crosslinking with metal ions (e.g. $\mathrm{Eu}^{3+}$, $\mathrm{Ru}^{2+}$ and $\mathrm{Zn}^{2+}$ ), which has been applied in the fabrication of metal coordination crosslinked polymer micelles. ${ }^{37}$ Alginate is known to form a hydrogel in the presence of divalent cations, such as calcium, which acts as crosslinker between the functional groups of alginate chains. ${ }^{38}$ In recent years, various kinds of metal ions (e.g. $\mathrm{Ni}^{2+}, \mathrm{Co}^{2+}$ and $\mathrm{Mg}^{2+}$ ) were utilized to crosslink the alginate to prepare the flame-retardant films and fibers. ${ }^{39}$ In principle, metalligand interactions can be utilized for intrinsic self-healing, as the reformation of coordinative bonds does not require demanding conditions, such as high pressure or harsh chemical environment, but it can occur in situ for polymers in a suitable environment. It has been reported that the hexabrachial star copolymer system crosslinked by ferric (II) salt shows good self-healing performance at the medium temperature of $80-120^{\circ} \mathrm{C}$ and the time interval of 6-8 $\mathrm{h}$, which was better than for the linear polymer system. ${ }^{40}$ Based on the unique advantages of metal ion crosslinking, such as forming a reversible network and simply tuning material properties, it has also been applied to polyethylene glycol (PEG)based links, crosslinked with metal ions $\left(\right.$ e.g. $\mathrm{V}^{3+}, \mathrm{Fe}^{3+}$, and $\left.\mathrm{Al}^{3+}\right)$ as materials for $3 \mathrm{D}$ extrusion printing, thus facilitating the adaptation of the system to the requirements of the printing process broad range of the printing parameters and application with remarkable flexibility. ${ }^{41}$ All in all, metal crosslinking is a good way to adjust and assemble materials, which has been successfully applied in many fields.

The specific mechanisms of the relationship between doping, crosslinking or impurity elements and properties are still unclear and worthy of further study, especially regarding the Materials Genome Initiative. The composition and microstructure, just like "genes" which determine the properties of materials, of the metallic elements are essential components of various gene sequences. Thus, it is important to materials science that the distribution, species, and content of doping, crosslinking or impurity elements, and the effects on the resulting properties of the materials. Therefore, the "concept of matermetallomics" is defined as a structure-activity relationship of materials between their components and their properties and performance. Furthermore, the techniques for characterizing the distribution, species, and content of metallic elements in materials are discussed detailed in section "Analytical approaches for matermetallomics". Although many related studies have been published recently, only representative work is cited here.

\section{METARMETALLOMIC AND RELATED TERMS}

In the study of metallomics, it refers to the study of a metallome, interactions and functional connections of metal ions and their species with genes, proteins, metabolites and other biomolecules within organisms and ecosystems. The most important research target of metallomics is to elucidate the physiological roles and functions of the biomolecules binding with metallic ions in the biological systems. ${ }^{42}$ Similarly, metallomics of materials should clarify the role and function of metallic elements in materials, named as Matermetallomics. It is therefore important to specify that a metallomics study implies:

(i) A focus on metallic or semi-metallic elements (e.g. As, Se, Sb) in the context of materials science. It is not recommended to extend the term extended to non-metals, such as sulfur or phosphorous.

(ii) A correlation of the element concentration mapping or element speciation with materials. This correlation may be statistical (the distribution, content and species of elements coincides with the presence of a particular property or character), structural (the interaction between the elements and microstructure) or functional (the presence of elements is the result of process adjustment).

(iii) A systematic, comprehensive, or global approach. If a metal species does not explain its significance and contribution to materials science, it is not matermetallomics!

Matermetallome is defined as the distribution, species, and concentration of metal elements in micro and macro structures. From the above consideration, a matermetallome refers to the metallic matrix, dopants, impurities or crosslinkers in inorganic nonmetal materials, polymer materials and composite materials.

\section{ANALYTICAL APPROACHES FOR MATERMETALLOMICS}

In the study on the subjects in matermetallomics, many existing analytical techniques have been widely used, more advanced 
Table 2 Representative Analysis Methods in Material Analysis

\begin{tabular}{|c|c|c|c|}
\hline Analyte & Analysis Method & Comments & Ref. \\
\hline $\mathrm{Cr}, \mathrm{Co}, \mathrm{Ni}$, and $\mathrm{Cu}$ & LA-ICP-MS & $\begin{array}{l}\text { Quantitative analysis of } \mathrm{Cr}, \mathrm{Co}, \mathrm{Ni} \text { and } \mathrm{Cu} \text { in metallic materials without } \\
\text { complex processing. }\end{array}$ & 43 \\
\hline ratio of $\mathrm{Fe}$ (II)/ $/ \mathrm{Fe}$ (III) & XPS & Analyze the ratio of $\mathrm{Fe}$ (II)/Fe (III) in 1045 steel and J55 steel. & 44 \\
\hline $\mathrm{Cr}, \mathrm{Fe}, \mathrm{Ni}$ & SIMS & Depth-profiling analysis of $\mathrm{Cr}, \mathrm{Fe}, \mathrm{Ni}$ in oxidized steel samples. & 45 \\
\hline Th and $U$ & ICP-MS & Detect ultra-trace Th and U in copper & 46 \\
\hline $\begin{array}{l}\text { Sc, Y, La, Ce, Pr, Nd, Sm, } \\
\text { Eu, Gd, Tb, Dy, Ho, Er, Tm, } \\
\text { Yb, Lu, Th }\end{array}$ & $\begin{array}{l}\text { Glow discharge mass } \\
\text { spectrometry (GD-MS) }\end{array}$ & Qualitative analysis of 72 impurity elements in high-purity copper powder. & 47 \\
\hline $\begin{array}{l}\mathrm{Cd}, \mathrm{Cr}, \mathrm{Mn}, \mathrm{Mo}, \mathrm{Pb}, \mathrm{V}, \text { and } \\
\mathrm{Zn}\end{array}$ & $\begin{array}{l}\text { Electrothermal vaporization } \\
\text { (ETV)-ICP-AES }\end{array}$ & $\begin{array}{l}\text { Determination of } \mathrm{Cd}, \mathrm{Cr}, \mathrm{Mn}, \mathrm{Mo}, \mathrm{Pb}, \mathrm{V} \text { and } \mathrm{Zn} \text { in } 2.0-2.5 \mathrm{mg} \text { aliquots of } \\
\text { nickel foam samples without pretreatment. }\end{array}$ & 48 \\
\hline $\begin{array}{l}\mathrm{Cr}, \mathrm{Mn}, \mathrm{Fe}, \mathrm{Co}, \mathrm{Ni}, \mathrm{Cu}, \mathrm{Zn} \text {, } \\
\text { As and } \mathrm{Pb} \text { at trace level }\end{array}$ & Total reflection-XRF & $\begin{array}{l}\text { Quantify trace elements in light and middle distillates (gasoline, racing and } \\
\text { jet fuel). }\end{array}$ & 49 \\
\hline $\begin{array}{l}\text { sulfur and iron valence } \\
\text { state }\end{array}$ & $\begin{array}{l}\text { Wavelength dispersion } \\
\text { (WD)-XRF }\end{array}$ & $\begin{array}{l}\text { Determine the content of ferrous iron and to estimate sulfur valence state in } \\
\text { coal concentrates and ashes from the pressed pellet without additional } \\
\text { sample preparation. }\end{array}$ & 50 \\
\hline lithium isotopic & MC-ICP-MS & $\begin{array}{l}\text { Determination of lithium isotopes in coal to help to track atmospheric haze } \\
\text { and polluted water in the environment. }\end{array}$ & 51 \\
\hline $\mathrm{C}, \mathrm{H}, \mathrm{Ni}, \mathrm{S}$ and $\mathrm{V}$ & LIBS\&LA-ICP-AES & $\begin{array}{l}\text { LIBS and LA-ICP-AES were used simultaneously for the elemental } \\
\text { analysis of asphaltene samples using minimum sample pretreatment. }\end{array}$ & 52 \\
\hline $\mathrm{Cr}, \mathrm{Hg}$ and $\mathrm{Pb}$ & LIBS & $\begin{array}{l}\text { Quantitative analysis of plastics by LIBS was used to measure } \mathrm{Cr}, \mathrm{Hg} \text { and } \\
\mathrm{Pb} \text {. }\end{array}$ & 53 \\
\hline $\begin{array}{l}\text { the }{ }^{137} \mathrm{Cs} \text { and }{ }^{40} \mathrm{~K} \text { radio } \\
\text { isotopes }\end{array}$ & $\begin{array}{l}\text { High purity germanium } \\
\text { gamma spectrometry } \\
\text { (HPGe) }\end{array}$ & $\begin{array}{l}\text { The HPGe method was used to detect the concentration of }{ }^{137} \mathrm{Cs} \text { and }{ }^{40} \mathrm{~K} \\
\text { isotope in edible salt. }\end{array}$ & 54 \\
\hline Pd, Pt and Rh & $\begin{array}{l}\text { High resolution continuum } \\
\text { source graphite furnace } \\
\text { (HR-CS)-GFAAS }\end{array}$ & $\begin{array}{l}\text { HR-CS-GFAAS detected the Pd, Pt and Rh (PGMs) in spent automobile } \\
\text { catalysts without chemical separation. }\end{array}$ & 55 \\
\hline $\begin{array}{l}\text { gas concentrations below a } \\
\text { tungsten surface }\end{array}$ & LIBS-LAMS & $\begin{array}{l}\text { LIBS-LAMS was used to measure the depth-dependent concentration of } \\
\text { gaseous substances under the surface of tungsten. }\end{array}$ & 56 \\
\hline${ }^{235} \mathbf{U}{ }^{238} \mathbf{U}$ ratio & NanoSIMS & $\begin{array}{l}\text { The micro-scale isotopic heterogeneity of nuclear fuel pellets was } \\
\text { characterization by nano-scale secondary ion mass spectrometry } \\
\text { (NanoSIMS). }\end{array}$ & 57 \\
\hline two $\mathrm{Cm}$ isotopic ratios & AMS & $\begin{array}{l}\text { Two Cm isotopic ratios }\left({ }^{244} \mathrm{Cm} /{ }^{246} \mathrm{Cm} \text { and }{ }^{245} \mathrm{Cm} /{ }^{246} \mathrm{Cm}\right) \text { was determined to } \\
\text { date irradiated in nuclear fuels. }\end{array}$ & 58 \\
\hline $\mathrm{Cu}, \mathrm{Zr}, \mathrm{Ag}, \mathbf{W}$ & FIB-TOF-SIMS & High spatial resolution of elemental distribution was determined. & 59 \\
\hline $\mathrm{Cu}, \mathrm{Se}, \mathrm{In}, \mathrm{Ga}$ & GD-OES & $\begin{array}{l}\text { GD-OES was used for quantitative depth-profiling of copper indium } \\
\text { gallium sulfur selenide (CIGS) thin films. }\end{array}$ & 60 \\
\hline $\mathrm{Mn}, \mathrm{Cu}, \mathrm{Fe}$ & $\begin{array}{l}\text { Electron probe micro } \\
\text { analyzer (EPMA) }\end{array}$ & $\begin{array}{l}\text { EPMA was used to measure the partial substitution of iron in the TiFe- } \\
\text { system. }\end{array}$ & 61 \\
\hline $\begin{array}{l}\mathrm{Al}, \mathrm{Si}, \mathrm{K}, \mathrm{Ca}, \mathrm{Ti}, \mathrm{Mn}, \mathrm{Fe} \\
\mathrm{Cu}, \mathrm{Zn} \text { and } \mathrm{Sr}\end{array}$ & PIXE & Multi-elements and non-destructive analysis on the young leaves of Neem. & 62 \\
\hline $\mathbf{N a}, \mathbf{M g}, \mathbf{A l}$ & PIGE & $\begin{array}{l}\text { In-situ quantitative analysis of four main elements (silicon, sodium, } \\
\text { magnesium, and aluminum) in the soda lime glass sample. }\end{array}$ & 63 \\
\hline Sc & NMR & $\begin{array}{l}\text { Solid-state NMR }\left({ }^{45} \mathrm{Sc} \text { MAS NMR) was used to measure the }\right. \\
\text { intramolecular charge transfers, which confirmed clearly the increase of } \\
\text { electron density around the } \mathrm{Sc}^{3+} \text { species after Sc-EBTC interacted with the } \\
\text { analytes. }\end{array}$ & 64 \\
\hline $\begin{array}{l}\text { Complexation of } \\
\text { terpolymer and } \mathrm{Ga} \text { ions }\end{array}$ & HPLC & $\begin{array}{l}\text { HPLC was used to characterize the complexation of the terpolymer and Ga } \\
\text { ions. }\end{array}$ & 65 \\
\hline $\mathbf{N a}$ & MALDI-TOF-MS & $\begin{array}{l}\text { MALDI-TOF MS spectra showed the ionization with } \mathrm{H}^{+} \text {and } \mathrm{Na}^{+} \text {were } \\
\text { almost the same to the theoretical calculated values, confirmed chemical } \\
\text { structure of octa carboxyl polyhedral oligomeric silsesquioxane. }\end{array}$ & 66 \\
\hline $\begin{array}{l}\text { Microstructure of } \\
\mathrm{La}_{2} \mathrm{CaB}_{10} \mathrm{O}_{19} \text { crystal }\end{array}$ & Raman spectrometer & $\begin{array}{l}\text { In situ Raman spectroscopy was applied to obtain the microstructure } \\
\text { information on } \mathrm{La}_{2} \mathrm{CaB}_{10} \mathrm{O}_{19} \text { crystal and its growth solution. }\end{array}$ & 67 \\
\hline Titanate & FTIR & $\begin{array}{l}\text { FTIR measured the typical stretching vibrations band of Ti-O, explained } \\
\text { the molecular structure of titanate nanofibers. }\end{array}$ & 68 \\
\hline
\end{tabular}

analytical techniques are also needed to explore the new research fields. Some representative analysis methods in materials analysis are listed in Table 2. The analytical techniques were split into five main sections based on the research subject. 
1. Imaging techniques mainly refer to element imaging, includes microscope and traditional spectroscopic techniques. Electron microscopes combined with energy dispersion X-ray analysis (EM-EDS) are the instruments specifically developed to acquire images of target materials at high magnification and analyze the elements on surface or cross-sections of materials, but its disadvantage is that it cannot analyze elements with an atomic number less than 5, in addition, the elemental sensitivity is poor. The new methods based on laser plasma technology are also gradually used in the imaging of elements in materials, such as laser-induced breakdown spectroscopy (LIBS) and laser ablation inductively coupled plasma mass spectrometry (LA-ICP-MS). LIBS is an imaging technology developed in recent years. Its advantages are that it can realize micro-area and fast elemental analysis without complicated preparation. Its disadvantages are poor stability, high sensitivity (up to $\mu \mathrm{g} / \mathrm{g}$ level). In addition, the LIBS method can be applied to qualitative and quantitative analysis of elements, as well as in situ and remote real-time analysis such as iron and steel smelting.

2. Spectroscopic techniques, such as infrared, Raman spectroscopies and nuclear magnetic resonance (NMR), are frequently used to characterize the molecular structure in inorganic and organic compounds. The FTIR method is a nondestructive analysis and free from the restriction of the sample's physical state, but it is suitable for qualitative analysis, rarely for quantitative analysis. Raman spectroscopy can obtain the microstructure information of materials, such as bond length, coordination number information, cluster information with different coordination numbers, and quantitatively obtain the corresponding content of the microstructure types. What's more, it can be used for in situ detection at high temperature. High temperature in situ analysis technology also includes XRD, NMR. NMR is the most frequently used method for molecular structure characterization, which can obtain sample structure, composition, and kinetic information under non-destructive conditions with highly specific and good repeatability, but its low sensitivity limits its application in low doped materials.

3. X-ray-based technologies have a wide range of applications. $\mathrm{X}$-ray fluorescence (XRF) is one of the most frequently used techniques for elemental analysis because of the advantages of fast analysis speed and no complex preprocessing. Its disadvantages are that the sensitivity to low atomic number elements is lower and it is easily affected by mutual element interference and overlapping peaks. X-ray diffraction (XRD) is often used for phase structure analysis, but it can also be used for component analysis of materials. X-ray photoelectron spectroscopy (XPS) is applied to quantify the valence and electronic levels of specific elements at the micro-area surface, which can analyze all elements, except $\mathrm{H}$ and $\mathrm{He}$, and the qualitative identification of elements is strong. But elemental sensitivity is low, $0.1 \%$ of detection limit, and data acquisition is slower.

4. Ion beam techniques can quantify trace elements with high sensitivity. Particle-induced X-ray emission (PIXE) and proton-induced gamma-ray emission (PIGE) have the advantages of high sensitivity, micro loss, and micro area analysis, but elements can be analyzed $\mathrm{Z}>12$.

5. MS-based techniques are most widely used for identification of unknown species, content determination and distribution imaging. Gas/liquid chromatography-MS is mainly applied to identify unknown organic substances containing metallic elements, but the analysis time is generally longer than with other MS-based techniques. Secondary ion mass spectroscopy (SIMS) is a very sensitive method for surface composition analysis, which can analyze all elements or isotopes including hydrogen, and depth analysis can be performed on samples with a depth resolution of less than 1 nanometer. However, it is very difficult to quantitative analysis because of the great difference between the secondary ion difference values of various elements. The secondary ion transmission efficiency of the mass analyzer is low and the measurement accuracy is insufficient. Matrix-assisted laser desorption ionization timeof-flight mass spectrometry (MALDI-TOF-MS) is a mass spectrometry technique developed in the late 1980 s, which is widely used in protein sequencing and microbial identification. It has the advantages of fast analysis speed, high resolution $(\mu \mathrm{m})$, high sensitivity (f mol), high flux and high precision. It cannot analyze non-covalent bond interactions because of the soft ionization mode. ICP-MS is also a sensitive element analysis technology, which can realize micro area analysis of solid samples combined with laser ablation.

6. Atomic spectrometry technology includes atomic absorption spectrometry (AAS), atomic emission spectrometry (AES) and atomic fluorescence spectrometry (AFS), and so on, which are common elemental quantitative techniques in materials analysis. So far, many techniques, such as XRF, ICPAES, ICP-MS as mature techniques, have been developed as the analytical methods for chemical speciation of trace metals in materials.

\section{CONCLUSIONS}

To meet the needs of human beings for materials, systematic and in-depth research of the quantitative relationship among composition, structure, process, properties, and performance is the most possible solution to solve the problem. In this context, matermetallomics is proposed to study the relationship between metallic components and materials. This includes the systematic study of the distribution, content and species of the metallic elements, and the interaction between the metallic elements and 
structure, process, properties, and performance. Further, it includes analytical approaches to matermetallomics and can be divided into six main categories: the imaging techniques, spectroscopic techniques, X-ray based techniques, ion beam techniques, MS-based techniques, and atomic spectrometry techniques. The emerging field of matermetallomics as an interdisciplinary field addresses the systematic view of the analytical methodology, role, and function of metallic elements in materials, across several disciplines including science and engineering of metallic materials, inorganic nonmetallic materials, polymer materials and composite materials, and materials characterization.

\section{AUTHOR INFORMATION}

\section{Corresponding Author}

*Z. Wang

Email address: wangzheng@mail.sic.ac.cn

\section{Notes}

The authors declare no competing financial interest.

\section{ACKNOWLEDGMENTS}

This work was supported by the National Consortium for Excellence in Metallomics and the Shanghai Platform for Metallomics, Science and Technology Innovation Project of Shanghai Institute of Ceramics, and Shanghai Technical Platform for Testing and Characterization on Inorganic Materials (19DZ2290700).

\section{REFERENCES}

1. Y. Li, L. Liu, W. Chen, and L. An, Sci. Sin. Chim., 2018, 48, 243-255. https://doi.org/10.1360/n032017-00182

2. C. M. Breneman, L. C. Brinson, L. S. Schadler, B. Natarajan, M. Krein, K. Wu, L. Morkowchuk, Y. Li, H. Deng, and H. Y. Xu, Adv. Funct. Mater, 2013, 23, 5746-5752. https://doi.org/10.1002/adfm.201301744

3. M. W. Gaultois, T. D. Sparks, C. K. H. Borg, R. Seshadri, W. D. Bonificio, and D. R. Clarke, Chem. Mat., 2013, 25, 2911-2920. https://doi.org/10.1021/cm400893e

4. R. Olivares-Amaya, C. Amador-Bedolla, J. Hachmann, S. Atahan-Evrenk, R. S. Sanchez-Carrera, L. Vogt, and A. Aspuru-Guzik, Energy Environ. Sci., 2011, 4, 4849-4861. https://doi.org/10.1039/c1ee02056k

5. B. B. Wang, L. L. Zhou, K. L. Xu, and Q. S. Wang, Ind. Eng. Chem. Res., 2017, 56, 47-51. https://doi.org/10.1021/acs.iecr.6b04347

6. M. A. Kuenemann, and D. Fourches, Mol. Inf., 2017, 36. 1600143. https://oi.org/10.1002/minf.201600143
7. C. E. Wilmer, M. Leaf, C. Y. Lee, O. K. Farha, B. G. Hauser, J. T. Hupp, and R. Q. Snurr, Nat. Chem., 2012, 4, 83-89. https://doi.org/10.1038/nchem.1192

8. S. R. Batten, N. R. Champness, X.-M. Chen, J. Garcia-Martinez, S. Kitagawa, L. Ohrstrom, M. O'Keeffe, M. P. Suh, and J. Reedijk, Pure Appl. Chem., 2013, 85, 1715-1724. https://doi.org/10.1351/pac-rec-12-11-20

9. K. V. Mahesh, R. Rashada, M. Kiran, A. P. Mohamed, and S. Ananthakumar, RSC Adv., 2015, 5, 51242-51247. https://doi.org/10.1039/c5ra07756g

10. C. H. Lu, G. V. Biesold, Y. J. Liu, Z. T. Kang, and Z. Q. Lin, Chem. Soc. Rev., 2020, 49, 4953-5007. https://doi.org/10.1039/c9cs00790c

11. G. C. Pan, X. Bai, D. W. Yang, X. Chen, P. T. Jing, S. N. Qu, L. J. Zhang, D. L. Zhou, J. Y. Zhu, W. Xu, B. Dong, and H. W. Song, Nano Lett., 2017, 17, 8005-8011. https://doi.org/10.1021/acs.nanolett.7b04575

12. G. G. Huang, C. L. Wang, S. H. Xu, S. F. Zong, J. Lu, Z. Y. Wang, C. G. Lu, and Y. P. Cui, Adv.Mater., 2017, 29. 1700095. https://doi.org/10.1002/adma.201700095

13. F. Sharifianjazi, M. Moradi, N. Parvin, A. Nemati, A. J. Rad, N. Sheysi, A. Abouchenari, A. Mohammadi, S. Karbasi, Z. Ahmadi, A. Esmaeilkhanian, M. Irani, A. Pakseresht, S. Sahmani, and M. S. Asl, Ceram. Int., 2020, 46, 18391-18412. https://doi.org/10.1016/j.ceramint.2020.04.202

14. S. Chakrabarty, A. Dutta, and M. Pal, Electrochim. Acta., 2015, 184, 70-79. https://doi.org/10.1016/j.electacta.2015.10.027

15. G. Muscas, S. Jovanovic, M. Vukomanovic, M. Spreitzer, and D. Peddis, J. Alloy. Compd., 2019, 796, 203-209. https://doi.org/10.1016/j.jallcom.2019.04.308

16. H. Li, X. Hao, C. Wang, R. Zhang, H. Liu, and S. Wang, Chin. Ceram., 2016, 52, 1-7. http://doi.org/10.16521/j.cnki.issn.1001-9642.2016.08.001

17. M. Shakil, A. Hussain, M. Zafar, S. Ahmad, M. I. Khan, M. K. Masood, and A. Majid, Chin. J. Phys., 2018, 56, 1570-1577. https://doi.org/10.1016/j.cjph.2018.05.018

18. A. Ghosh, O. F. Mohammed, and O. M. Bake, Accounts Chem. Res., 2018, 51, 3094-3103. https://doi.org/10.1021/acs.accounts.8b00412

19. M. K. Shobana, W. Nam, and H. Choe, J. Nanosci. Nanotechnol., 2013, 13, 3535-3538. https://doi.org/10.1166/jnn.2013.7250

20. Y. M. L. Yang, L. B. Qiu, W. T. A. Harrison, R. Christoffersen, and A. J. Jacobson, J. Mater. Chem., 1997, 7, 243-248. https://doi.org/10.1039/a604694k

21. M. Alga, M. Wahbi, A. Ammar, B. Tanouti, J. C. Grenier, and J. M. Reau, J. Alloy. Compd., 1997, 256, 234-243. https://doi.org/10.1016/s0925-8388(96)03106-4

22. R. K. Behera, S. Das Adhikari, S. K. Dutta, A. Dutta, and N. Pradhan, J. Phys. Chem. Lett., 2018, 9, 6884-6891. https://doi.org/10.1021/acs.jpclett.8b03047

23. J. K. Chen, J. P. Ma, S. Q. Guo, Y. M. Chen, Q. Zhao, B. B. Zhang, Z. Y. Li, Y. Zhou, J. S. Hou, Y. Kuroiwa, C. Moriyoshi, O. M. Bakr, J. Y. Zhang, and H. T. Sun, Chem. Mat., 2019, 31, 3974-3983. https://doi.org/10.1021/acs.chemmater.9b00442

24. K. Kamiya, Chem. Sci., 2020, 11, 8339-8349. https://doi.org/10.1039/d0sc03328f

25. V. Trepakov, M. Savinov, S. Prosandeev, P. Syrnikov, A. Pashkin, J. Petzelt, S. Kapphan, and L. Jastrabik, Ferroelectrics, 2004, 302, 449-452. https://doi.org/10.1080/00150190490453711

26. M. Bulinski, V. Kuncser, C. Plapcianu, S. Krautwald, H. Franke, 
P. Rotaru, and G. Filoti, J. Phys. D-Appl. Phys., 2004, 37, 2437-2441. https://doi.org/10.1088/0022-3727/37/17/015

27. J. X. Fang, A. M. Thompson, M. P. Harmer, and H. M. Chan, J. Am. Ceram. Soc., 1997, 80, 2005-2012. https://doi.org/10.1111/j.1151-2916.1997.tb03084.x

28. S. Yang, X. Xing, J. Zhang, H. Wang, L. Sima, and H. Wang, J. Funct. Mater., 2018, 49, 6190-6195. http://doi.org/10.3969/j.issn.1001-9731.2018.06.032

29. N. S. Akhmadullin, O. N. Shishilov, and Y. F. Kargin, Russ. Chem. Bull., 2020, 69, 825-837. https://doi.org/10.1007/s11172-020-2841-4

30. V. Hasija, P. Raizada, A. Sudhaik, K. Sharma, A. Kumar, P. Singh, S. B. Jonnalagadda, and V. K. Thakur, Appl. Mater. Today., 2019, 15, 494-524. https://doi.org/10.1016/j.apmt.2019.04.003

31. F. Y. Fan, J. J. Zhang, J. Li, N. Zhang, R. R. Hong, X. C. Deng, P. G. Tang, and D. Q. Li, Sens. Actuator B-Chem., 2017, 241, 895-903. https://doi.org/10.1016/j.snb.2016.11.025

32. A. Sanchez Arribas, M. Moreno, M. Martinez-Fernandez, E. Bermejo, A. Zapardiel, and M. Chicharro, Sens. Actuator B-Chem., 2013, 182, 31-39. https://doi.org/10.1016/j.snb.2013.02.083

33. A. V. Talyzin, and A. Dzwilewski, J. Nanosci. Nanotechnol., 2007, 7, 1151-1161. https://doi.org/10.1166/jnn.2007.304

34. V. Kveder, M. Kittler, and W. Schroter, Phys. Rev. B., 2001, 63, 115208. https://doi.org/10.1103/PhysRevB.63.115208

35. M. Pumera, and Y. Miyahara, Nanoscale, 2009, 1, 260-265. https://doi.org/10.1039/b9nr00071b

36. Z. Liu, W. He, and Z. Guo, Chem. Soc. Rev., 2013, 42, 1568-1600. https://doi.org/10.1039/c2cs35363f

37. M. Lin, Y. Dai, F. Xia, and X. Zhang, Mat. Sci. Eng. C-Mater, 2021, 119. 111626 . https://doi.org/10.1016/j.msec.2020.111626

38. H. T. Bu, A. L. Kjoniksen, K. D. Knudsen, and B. Nystrom, Biomacromolecules, 2004, 5, 1470-1479. https://doi.org/10.1021/bm049947+

39. Y. Pan, W. Wang, L. X. Liu, H. Ge, L. Song, and Y. Hu, Carbohydr. Polym., 2017, 170, 133-139. https://doi.org/10.1016/j.carbpol.2017.04.065

40. J. Handique, J. Gogoi, and S. K. Dolui, J. Appl. Polym. Sci., 2020, 137. 48527. https://doi.org/10.1002/app.48527

41. M. K. Wlodarczyk-Biegun, J. I. Paez, M. Villiou, J. Feng, and A. del Campo, Biofabrication, 2020, 12. 035009. https://doi.org/10.1088/1758-5090/ab673a

42. H. Haraguchi, J. Anal. At. Spectrom., 2004, 19, 5-14. https://doi.org/10.1039/b308213j

43. Y. Makino, Y. Kuroki, and T. Hirata, J. Anal. At. Spectrom., 2019, 34, 1794-1799. https://doi.org/10.1039/c9ja00181f

44. P. Wongpanya, Y. Saramas, C. Chumkratoke, and A. Wannakomol, J. Pet. Sci. Eng., 2020, 189. 106965. https://doi.org/10.1016/j.petrol.2020.106965

45. M. Miśnik, P. Konarski, A. Zawada, and J. Ażgin, Nucl. Instrum. Meth. B., 2019, 450, 153-156. https://doi.org/10.1016/j.nimb.2018.05.017

46. I. J. Arnquist, M. L. di Vacri, and E. W. Hoppe, Nucl. Instrum. Meth. A., 2020, 965. 163761. https://doi.org/10.1016/j.nima.2020.163761
47. J. Zhang, T. Zhou, Y. Cui, Y. Tang, and B. Wu, J. Anal. At. Spectrom., 2020, 35, 2712-2722. https://doi.org/10.1039/d0ja00327a

48. K. Harrington, A. Al Hejami, and D. Beauchemin, J. Anal. At. Spectrom., 2020, 35, 461-466. https://doi.org/10.1039/c9ja00400a

49. A. Cinosi, G. Siviero, D. Monticelli, and R. Furian, Spectrochim. Acta, Part B, 2020, 164. 105749. https://doi.org/10.1016/j.sab.2019.105749

50. V. M. Chubarov, A. A. Amosova, and A. L. Finkelshtein, Spectrochim. Acta, Part B, 2020, 163. 105745. https://doi.org/10.1016/j.sab.2019.105745

51. M.-Y. He, C.-g. Luo, H. Lu, Z. d. Jin, and L. Deng, J. Anal. At. Spectrom., 2019, 34, 1773-1778. https://doi.org/10.1039/c9ja00204a

52. D. Oropeza, J. González, J. Chirinos, V. Zorba, E. Rogel, C. Ovalles, and F. López-Linares, Appl. Spectrosc., 2019, 73, 540-549. https://doi.org/10.1177/0003702818819497

53. K. Liu, D. Tian, H. Xu, H. Wang, and G. Yang, Anal. Methods., 2019, 11, 4769-4774. https://doi.org/10.1039/c9ay01796h

54. F. Caridi, M. Messina, A. Belvedere, M. D'Agostino, S. Marguccio, L. Settineri, and G. Belmusto, Appl. Sci., 2019, 9. 2882. https://doi.org/10.3390/app9142882

55. V. V. Eskina, O. A. Dalnova, D. G. Filatova, V. B. Baranovskaya, and Y. A. Karpov, Spectrochim. Acta, Part B, 2020, 165. 105784. https://doi.org/10.1016/j.sab.2020.105784

56. G. Shaw, W. Garcia, X. Hu, and B. D. Wirth, Phys. Scr., 2020, T171, 014029. https://doi.org/10.1088/1402-4896/ab47c7

57. R. Kips, P. K. Weber, M. J. Kristo, B. Jacobsen, and E. C. Ramon, Anal. Chem., 2019, 91, 11598-11605. https://doi.org/10.1021/acs.analchem.9b01737

58. M. Christl, N. Guérin, M. Totland, A. Gagné, Z. Kazi, S. Burrell, and H.-A. Synal, J. Radioanal. Nucl. Chem., 2019, 322, 1611-1620. https://doi.org/10.1007/s10967-019-06767-4

59. A. Priebe, I. Utke, L. Pethö, and J. Michler, Anal. Chem., 2019, 91, 11712-11722. https://doi.org/10.1021/acs.analchem.9b02287

60. T. Kodalle, D. Greiner, V. Brackmann, K. Prietzel, A. Scheu, T. Bertram, P. Reyes-Figueroa, T. Unold, D. Abou-Ras, R. Schlatmann, C. A. Kaufmann, and V. Hoffmann, J. Anal. At. Spectrom., 2019, 34, 1233-1241. https://doi.org/10.1039/c9ja00075e

61. E. M. Dematteis, F. Cuevas, and M. Latroche, J. Alloy. Compd., 2021, 851. 156075. https://doi.org/10.1016/j.jallcom.2020.156075

62. V. Sharma, R. Acharya, S. K. Samanta, M. Goswami, H. K. Bagla, and P. K. Pujari, J. Radioanal. Nucl. Chem., 2019, 323, 1451-1457. https://doi.org/10.1007/s10967-019-06926-7

63. M. Elayaperumal, Y. Vedachalam, D. Loganathan, T. A. Kumaravelu, G. S. Anusuya, and J. Kennedy, Biol. Trace. Elem. Res., 2020. https://doi.org/10.1007/s12011-020-02443-x

64. D. Zhan, A. Saeed, Z. Li, C. Wang, Z. Yu, J. Wang, N. Zhao, W. Xu, and J. Liu, Dalton. Trans., 2020, 49, 17737-17744. https://doi.org/10.1039/d0dt03781h 